\title{
Úroveň pohybovej výkonnosti mladých basketbalistiek, reprezentantiek Slovenska v kategórii U14
}

\section{The performance level of young national basketball players of Slovakia U14}

\author{
Ladislava Doležajová', Tatiana Gallová2, Anton Lednický' \\ ${ }^{1}$ Fakulta telesnej výchovy a športu UK Bratislava \\ ${ }^{2}$ Bulls Kapfenberg U19, Rakúsko
}

\begin{abstract}
Abstrakt
Na Slovensku v basketbale dlhodobo absentuje systematické sledovanie a hodnotenie vývinu mladých hráčok. Prvé testovanie širšieho výberu U14 $(n=44)$ sa uskutočnilo na podnet reprezentačnej trénerky tejto vekovej kategórie. Výsledky ukázali, že základné somatické ukazovatele je potrebné doplnit' o meranie podkožného tuku a spresnenie biologického veku probandiek. Telesná výška basketbalistiek v porovnaní s populáciou bola vyššia, až dve tretiny hráčok bolo v skupine nadpriemernej, resp. výrazne nadpriemernej. Potvrdila sa nezávislost'pohybovej výkonnosti od somatických ukazovatelov v testoch rýchlostného charakteru. Voblasti pohybovej výkonnosti boli realizované predovšetkým testy všeobecnej pohybovej výkonnosti, ktoré sme doplnili špeciálnymi, basketbalovými testami.
\end{abstract}

\begin{abstract}
In Slovak basketball absent a systematic monitoring and evaluation of the development of young players. The first measurement of the wider selection of U14 $(n=44)$ was carried out at the initiative of a national coach of this age category. The results show us, that the basic somatic indicators need to be completed by subcutaneous fat measurement and the biological age of probands. Physical height of basketball players compared with the population was higher. Up to two-thirds of the players were in above the average group, respectively significantly above average. The independence of movement performance from somatic indicators in speed targeting tests was confirmed. In the area of the movement performance were carried out tests of general movement, which should have to be completed by special basketball tests.
\end{abstract}

Klúčové slová: testovanie, vybrané pohybové schopnosti, mladé basketbalistky, širší káder reprezentácie SR v kategórii U14.

Keywords: motor abilities tests, young basketball women players, U14 Slovak national team - pre select.

\section{ÚVOD}

Basketbal patrí medzi náročné a dynamické športové hry, ktorá kladie vysoké požiadavky na kondíciu hráčov, preto sa v nej výrazne uplatňuje atletická príprava (Gallová, Doležajová, \& Lednický, 2010; Šimonek, 1987). Sú však aj názory, podl’a ktorých je basketbalový výkon primárne záležitostou koordinačnou a až sekundárne kondičnou. Aj takéto protichodné názory sú príčinou rôznych problémov spojených s tvorbou požiadaviek na efektívny výber mladých hráčov. Nielen pri prvotnom výbere, ale aj do mládežníckych reprezentačných tímov. Sme toho názoru, že tento proces je podmienený existenciou jasných testovacích kritérií, na základe ktorých by sa výberové konanie uskutočnilo. 
Charakteristika basketbalu často zvádza k preceňovaniu somatických ukazovatel'ov, predovšetkým telesnej výšky. Na celkové hodnotenie mladých hráčok je však nutné sa pozerat diferencovane a individuálne. Nadpriemerná telesná výška a nerovnomerný telesný a motorický rozvoj, spolu so špecifikami jednotlivých postov, schopnostami motorického učenia sa špecifickým drilom v konkrétnych herných situáciách, psychická vytrvalost’ a odolnosṫ, taktické myslenie, spolu s možnostou pomerne značnej kompenzácie v mládežníckych kategóriách, ktorá sa vo vyšších etapách prípravy znižuje, nabáda k opatrnosti pri formulovaní jednoznačných kategorických záverov. Vysoká úroveň pohybovej výkonnosti všestranného charakteru, najmä v rýchlostných, rýchlostno-silových a vytrvalostných testoch vytvára však lepšie predpoklady pre finálny športový výkon. Vd’aka nim hráčka má vyšší pohybový potenciál, ktorý môže efektívne uplatnit tak v dlhodobej športovej príprave ako aj v konkrétnom športovom zápase. Vo vrcholovom basketbale sa uplatnili aj hráčky, ktoré svojimi somatickými parametrami boli d’aleko od tých, ktoré sa považujú za ideálne napr. pivotka $190 \mathrm{~cm}$ a $114 \mathrm{~kg}$.

V Európe sa mladým talentovaným hráčkam i hráčom basketbalu venuje zvýšená pozornost (Erčulj, Dežman, Vučković, \& Bračič, 2007). Na Slovensku zatial' neexistuje ucelený jednotný systém na testovanie úrovne pohybových schopností basketbalistiek v kluboch. Vo vyšších vekových kategóriách reprezentačných tímov mládeže (U16, U18, U20) realizujú jednorazové testovanie len niektorí tréneri v prípravnom období pred $\mathrm{ME}$, a to len $\mathrm{v}$ maximálne $\mathrm{v}$ troch až štyroch kondičných schopnostiach.

\section{CIEL'}

Zistit úroveň somatických ukazovatel’ov a pohybovej výkonnosti mladých basketbalistiek (13-až 14-ročné), členiek širšieho reprezentačného výberu SR v tejto vekovej kategórií (pre-selekcia) a vybrané ukazovatele porovnat's populáciou Slovenska.

\section{METODIKA}

Probandky, ktoré sa zúčastnili testovania boli vybrané basketbalistky vo veku 13 a 14 rokov $(n=44)$ $\mathrm{z}$ celého Slovenska. Testovanie sa realizovalo na podnet reprezentačnej trénerky U14 s najvyššou licenciou FIBA vzhl'adom na to, že dlhodobo absentuje testovania perspektívnych hráčov a hráčok $\mathrm{v}$ basketbale. Bolo to jedno z prvých testovaní pohybových schopností v tejto vekovej kategórii basketbalistiek. Výber testov sa uskutočnil jednak na základe trénerkinej skúsenosti, odbornej literatúry (Erčulj \& Bračič, 2008; Erčulj, 2008), ale aj časového priestoru, ktorý mali examinátori vyhradený na testovanie. $Z$ telesných ukazovatel'ov sme telesnú výšku merali pomocou laserového prístroja, telesnú hmotnost’ a vypočítali sme BMI index. Motorické testy tvorili štandardizované testy: akceleračný beh na $20 \mathrm{~m}$, akceleračný beh na $20 \mathrm{~m}$ s driblingom, rýchlostno-koordinačný beh 10x5 metrov, disjunktívno reakčno-rýchlostný test (vzdialenost platní bola $0,5 \mathrm{~m}$ od štartovacieho miesta), výskok bez a s protipohybom, hod plnou loptou $(2 \mathrm{~kg})$ zo stoja a zo sedu, vytrvalostný člnkový beh. Vo všetkých testoch mali probandky jeden zácvičný pokus a potom test vykonali podl'a odporúčaní autorov. Výsledkom bol najlepší pokus z realizovaných. Všetky rýchlostné behy sa merali fotobunkami, výbušná sila dolných končatín bola meraná na výskokovom ergometri fitro jumper. 


\section{Metódy spracovania a vyhodnotenia získaných údajov}

Pri spracovaní získaných údajov sme použili:

- základné štatistické charakteristiky (aritmetický priemer (x), variačné rozpätie (Vr), najlepší výkon $\left(\mathrm{x}_{\max }\right)$, najhorší výkon $\left(\mathrm{x}_{\min }\right)$, quartily $(\mathrm{Q} 1, \mathrm{Q} 3)$, párový korelačný koeficient podla Pearsona.

- logické metódy.

\section{VÝSLEDKY}

V basketbale patrí telesná výška medzi základné predpoklady úspešnosti hráčok. Je geneticky výrazne podmienená a nie je možné ju ovplyvnit vonkajšími činitel'mi. Z pohl'adu tohto ukazovatel'a bola skupina vybraných hráčok výrazne nehomogénna $\left(\mathrm{v}_{\mathrm{r}}=\right.$ takmer $\left.26 \mathrm{~cm}\right)$. Telesná hmotnost', ktorú je možné ovplyvnit stravou, tréningovým zatažením sa výrazne líšila a rozdiel medzi maximálnou a minimálnou hodnotou bol $37,5 \mathrm{~kg}$. V tab. 1 sú uvedené základné štatistické charakteristiky somatických ukazovatel'ov mladých basketbalistiek.

Tab. 1: Somatické ukazovatele mladých basketbalistov $(n=44)$

\begin{tabular}{|l|c|c|c|c|}
\hline Ukazovatel' & Decimálny vek (roky) & Telesná výška [cm] & Telesná hmotnost' [kg] & BMI (I) \\
\hline $\mathrm{x}$ & 14,08 & 171,99 & 60,66 & 20,51 \\
\hline $\mathrm{X}_{\max }$ & 14,44 & 184,80 & 82,50 & 24,16 \\
\hline $\mathrm{X}_{\min }$ & 13,48 & 159,00 & 45,00 & 17,89 \\
\hline $\mathrm{V}_{\mathrm{r}}$ & 0,96 & 25,90 & 37,50 & 6,27 \\
\hline $\mathrm{s}$ & 0,26 & 5,52 & 8,29 & 4,06 \\
\hline
\end{tabular}

Porovnanie ukazovatel'ov telesnej výšky s populáciou SR, ktoré vypracovali Sedláček \& Antala (2008) ukázalo, že 13-ročné basketbalistky majú zastúpenie v troch skupinách z pätdielnej stupnice. Žiadna $\mathrm{z}$ nich nebola $\mathrm{v}$ kategórii podpriemer, resp. výrazný podpriemer. Takmer polovica $\mathrm{z}$ nich bola v skupine nadpriemerne vysokých (tab. 2) a len 4 boli v skupine priemernej telesnej výšky.

V skupine 14-ročných hráčok sa tretina probandiek nachádzala v skupine nadpriemernej telesnej výšky, najmenej ich bolo v skupine priemernej telesnej výšky. Najviac dievčat bolo v tretej, najvyššej skupine. Sme si vedomí, že toto rozdelenie je informatívne. Vzhl'adom na individuálny vývin rastu probandiek v priebehu nasledujúceho obdobia sa rozdelenie môže výrazne zmenit.

Telesná hmotnost̉ 13-ročných probandiek bola najviac zoskupená na priemernej a nadpriemernej úrovni. Výrazne nadpriemernú hráčku sme zaregistrovali len jednu. Podobný trend bol aj v skupine starších hráčok s prevahou v skupine priemernej hmotnosti (17 z celkového počtu 28 basketbalistiek).

Index telesnej hmotnosti (BMI) športovcov je orientačný ukazovatel' (Buková \& Feč, 2014) pretože nezohl'adňuje pomer tuku a svalov. Rovnako vysokú hodnotu BMI môže mat športovec s vyššou svalovou hmotou ako aj nešportovec s prevahou tuku.

Výsledky testovania boli spracované pre lepšiu orientáciu trénerov pri výbere hráčok do výberu U14 a zároveň ako východisko pre odporúčanie pre staršie reprezentačné výbery. Na základe uvedeného rozdelenia môžeme predpokladat, že telesná výška zohrala výraznú úlohu pri výbere športovej špecializácie probandiek a orientovali sa tak, aby svoj somatický parameter využili v športe, v ktorom je dominantná. Tréneri, ktorí realizovali výber do prípraviek nemohli výrazne ovplyvnit zostavu detí, ktorá sa na ňom zúčastnila. 
Okrem somatických ukazovatel'ov sa na úspešnosti mladých basketbalistiek podiel'a aj úroveň rozvoja pohybových schopností. $\mathrm{V}$ tab. 3 uvádzame vybrané z nich, ktoré patria v basketbale medzi dominantné a ich vysoká úroveň môže do určitej miery kompenzovat nižšiu telesnú výšku hráčky.

Tab. 2: Zaradenie basketbalistiek do skupín v porovnaní s populáciou

\begin{tabular}{|c|c|c|c|c|c|}
\hline Ukazovatel' & & $\begin{array}{c}\text { Populácia SR } \\
\text { (13-ročné) }\end{array}$ & $\begin{array}{c}\text { Basketbalistky } \\
\text { (13-ročné) }\end{array}$ & $\begin{array}{c}\text { Populácia SR } \\
\text { (14-ročné) }\end{array}$ & $\begin{array}{c}\text { Basketbalistky } \\
\text { (14-ročné) }\end{array}$ \\
\hline \multirow{3}{*}{$\begin{array}{l}\text { Telesná výška } \\
{[\mathrm{cm}]}\end{array}$} & priemerná & $157-167$ & 4 & $159-169$ & 8 \\
\hline & nadpriemerná & $167,1-173$ & 8 & $169,1-175$ & 9 \\
\hline & $\begin{array}{c}\text { výrazne } \\
\text { nadpriemerná }\end{array}$ & Viac ako 173,1 & 5 & Viac ako 175,1 & 10 \\
\hline \multirow{3}{*}{$\begin{array}{l}\text { Telesná } \\
\text { hmotnost' [kg] }\end{array}$} & priemerná & $42-57$ & 8 & $46-61$ & 17 \\
\hline & nadpriemerná & $57,1-68$ & 7 & $61,1-72$ & 8 \\
\hline & $\begin{array}{c}\text { výrazne } \\
\text { nadpriemerná }\end{array}$ & Viac ako 68,1 & 1 & Viac ako 72,1 & 3 \\
\hline
\end{tabular}

Tab. 3: Štatistické spracovanie výkonnosti mladých basketbalistiek vo vybraných testových ukazovateloch

\begin{tabular}{|c|c|c|c|c|c|c|c|}
\hline Ukazovatel' & $\mathbf{x}$ & $\mathbf{x}_{\max }$ & $\mathbf{x}_{\min }$ & $\mathbf{V r}$ & $\mathbf{s}$ & Q1 & Q3 \\
\hline $\mathrm{VSHK}_{1}[\mathrm{~m}]$ & 6,85 & 10,20 & 5,10 & 5,10 & 0,94 & 6,20 & 7,35 \\
\hline $\mathrm{VSHK}_{2}[\mathrm{~m}]$ & 4,75 & 6,20 & 3,80 & 2,40 & 0,46 & 4,50 & 4,95 \\
\hline $20 \mathrm{~m}\left[\mathrm{~ms}^{-1}\right]$ & 3,57 & 3,98 & 3,22 & 0,76 & 0,18 & 3,67 & 3,45 \\
\hline $20 \mathrm{~m}$ dribling $\left[\mathrm{ms}^{-1}\right]$ & 3,77 & 4,32 & 3,32 & 1,00 & 0,18 & 3,86 & 3,64 \\
\hline VČB (n) & 66,33 & 103 & 47 & 56 & 12,75 & 56 & 70,5 \\
\hline Agilita [ms] & 837,85 & 988,70 & 671,90 & 316,80 & 82,40 & 896,35 & 782,80 \\
\hline $\begin{array}{l}\text { Výška výskoku s PP } \\
{[\mathrm{cm}]}\end{array}$ & 25,47 & 32,30 & 17,90 & 14,40 & 3,39 & 23,15 & 2790 \\
\hline $\begin{array}{l}\text { Výška výskoku bez PP } \\
{[\mathrm{cm}]}\end{array}$ & 23,51 & 29,40 & 17,40 & 12,00 & 2,94 & 21,75 & 25,65 \\
\hline
\end{tabular}

Legenda: VSHK - hod plnou loptou zo stoja, VSHK - hod plnou loptou zo sedu, $20 \mathrm{~m}$ - beh na $20 \mathrm{~m}$ akceleračne, $20 \mathrm{~m}$ dribling - beh na 20 m akceleračne s driblingom, VČB - vytrvalostný člnkový beh na úseku $20 \mathrm{~m}$, Agilita - senzomotorický čas, Výška výskoku s PP - výška výskoku s protipohybom, Výška výskoku bez PP - výška výskoku bez protipohybu.

\section{Výbušná sila horných končatín}

Výbušná sila horných končatín sa v basketbale využíva hlavne pri dlhých prihrávkach v súboji o loptu a pod. Realizovali sme dva testy - všeobecný: klasické autové vhadzovanie plnou loptou $2 \mathrm{~kg}$ a druhý test bol špeciálny: hod plnou loptou $2 \mathrm{~kg}$ zo sedu trčením od pŕs. Výber testov bol ovplyvnený faktom, že pri prvom teste sa do pohybovej činnosti zapája väčšie množstvo svalových skupín a jeho výsledky je možné porovnat s populáciou SR - priemerný výkon basketbalistiek $(6,85 \mathrm{~m})$ bol na úrovni vysoko nadpriemerného výkonu pre populáciu. Niektoré hráčky však mali výkon $(5,10 \mathrm{~m})$ len na úrovni priemeru populácie. Predpokladali sme, že pri tomto teste zohrala významnú úlohu aj telesná výška. To sa aj potvrdilo. Najlepší výkon na úrovni $10,20 \mathrm{~m}$ dosiahla hráčka vysoká $175 \mathrm{~cm}$, pritom najvyššia hráčka s telesnou výškou $184,8 \mathrm{~cm}$ mala výkon na úrovni $7,40 \mathrm{~m}$ a najnižšia s výškou $159 \mathrm{~cm}$ dosiahla výkon $6,70 \mathrm{~m}$. Pri realizácii druhého testu boli dominantne zapojené len horné končatiny (Erčulj, 2008,). Porovnaním výsledkov v obidvoch testoch sme zistili, že v druhom teste v skupine najlepších výkonov (Q3) bolo zastúpených viac hráčok ako v prvom teste (18, resp. 11). To svedčí o tom, že realizácia testu trčením od hrudi je 
pre hráčky prirodzenejšia ako autové vhadzovanie. Porovnanie výsledkov obidvoch testov dáva trénerovi možnost’ zistił jednak aktuálnu úroveň rozvoja výbušnej sily horných končatín a zároveň schopnost hráča koordinovane zapojit do činnosti podporné svalové skupiny. Táto kondičná schopnost̉ je základným predpokladom úspešnosti prihrávok, aj ked’ v herných situáciách si tieto vyžadujú časovú a priestorovú koordináciu minimálne medzi dvoma hráčmi.

\section{Rýchlostné schopnosti}

Zemková \& Hamar (2001) tvrdia, že rýchlost̉ je „dôležitým predpokladom úspešnosti“. V športových hrách môžeme hovorit o priamom behu resp. priamom šprinte iba minimálne. Byt pohybovo rýchlejši ako súper sa liši od lineárnej rýchlosti šprintéra. Rýchlost hráča je vo väčšine daná rýchlosţou zmeny smeru, akceleráciou, brzdením, protipohybom a pod. Na diagnostiku rýchlostných schopností existuje vel'ká škála testov, zameraných na jednotlivé rýchlostné prejavy. V basketbale však nie je zaužívaný štandard, ktorý by sa používal na ich testovanie. V basketbale zohráva rozhodujúcu úlohu tzv. herná rýchlost', ktorá je výslednicou základných rýchlostných prejavov: reakčná-senzomotorická a lokomočná rýchlost', rýchlost herných činností jednotlivca a herných kombinácií, rýchlost’ orientácie v hernej situácii a úroveň anticipácie (Čierna, 2013). V tréningu je dôležité rozvíjat jednotlivé zložky vo vzájomnom súlade, vzhl’adom k ich komplexnému prejavu $\mathrm{v}$ podmienkach hry. $\mathrm{V}$ našom výskume sme realizovali beh na $20 \mathrm{~m}$ akceleračne a špeciálny test beh na $20 \mathrm{~m}$ s driblingom, takisto akceleračne. Výber testov bol podmienený výsledkami autorov z vyspelých basketbalových krajín (v Litve Paulauskas (2003), v Slovinsku Simović, Mijanović (2007) a v USA Delextrat, Cohen (2008). V hladkom šprinte sa skupina najlepších (Q3) vyčlenila časom 3,45 s. V nej sa nachádzalo 12 hráčok, pričom až $11 \mathrm{z}$ nich mali nižšiu telesnú výšku ako priemer celého súboru. Predpokladáme, že to boli hráčky hrajúci na perimetri/obvode (rozohrávači a krídla). V tejto skupine bola len jedna hráčka vyššia ako bol priemer $(171,9 \mathrm{~cm})$. Z tejto skupiny najrýchlejších sa medzi najlepších v behu na $20 \mathrm{~m}$ s driblingom dostalo len 6 probandiek. To svedčí o určitých nedostatkoch $\mathrm{v}$ tejto individuálnej hernej činnosti. Je zaujímavé, že do skupiny najlepších v teste beh na $20 \mathrm{~m}$ s driblingom $(\mathrm{Q} 3=3,64 \mathrm{~s})$ sa dostali štyri hráčky s výkonmi od 3,48 s do $3,57 \mathrm{~s}$, ktoré neboli medzi najlepšími v hladkom šprinte. Porovnaním časov v obidvoch testoch môže tréner zistił zručnost̉ hráčov v behu s loptou, nakol'ko majú osvojený ballhandling (pushing dribble) pri priamočiarom pohybe. Beh na kratšie vzdialenosti (5, resp. 10 m) Kaplan (2014) aj na základe výsledkov iných autorov odporúča realizovat v kategórii dospelých športovcov.

\section{Senzomotorická reakčná schopnosti-agilita}

V súčasnosti je agilita vel’mi rozšíreným a často diskutovaným pojmom. Množstvo výskumov zaoberajúcich sa problematikou agility bolo vykonaných no aj napriek tomu sa autori stále konfrontujú s jej presnou definíciou (Labudová \& Peráček, 2013). Na čom sa však autori zhodli je fakt, že agilita je neuromuskulárna zručnost', ktorá je trénovatel'ná vo všetkých vekových a výkonnostných kategóriách (Holmberg 2015; Jeffreys 2006). V basketbale sa vyskytuje množstvo herných situácií, pri ktorých rýchlo po sebe nasleduje vykonávanie rôznorodých pohybov vpred, vzad, resp. do strán. Schopnost’ vykonávat tieto pohyby v čo najkratšom čase je vhodné zistovat pomocou testu, ktorý registruje nielen jednoduchý reakčný čas, ale aj schopnosṫ vykonat jednoduchú pohybovú činnost'. My sme použili test agility, pri ktorom bola vzdialenost platní $0,5 \mathrm{~m}$ od štartovacieho miesta (Zemková \& Hamar, 2001). Výsledky ukázali, že súbor bol nehomogénny. Priemerný výkon bol 837,85 ms a variačné rozpätie bolo na úrovni 316,80 ms. Potvrdili sme poznatok (Kampmiller, 1996), že táto schopnost̉ nie je výrazne ovplyvnená somatickými ukazovatel'mi. Najlepší výkon (671,90 ms) zaznamenala hráčka vysoká $165,5 \mathrm{~cm}$ a najhorší výkon (988,70 ms) mala hráčka s približne rovnakou telesnou výškou $(163,7 \mathrm{~cm})$. Najvyššia probandka 
( $184,8 \mathrm{~cm})$ dosiahla výkon na úrovni $855,80 \mathrm{~ms}$ ) čo bolo na úrovni priemerného výkonu súboru (837,85 ms). V skupine najlepších (Q3 = 782,80 ms) bolo 9 basketbalistiek. Výsledky v tomto teste boli dosiahnuté s vysokým podielom zrakového analyzátora a nervovo-svalovej koordinácie s eliminovaním ostatných pohybových schopností ako napr. vytrvalost' v rýchlosti. Koreláciou tohto ukazovatel'a (tab. 4) sme potvrdili jeho nezávislost' od ostatných sledovaných pohybových schopností. Tento fakt musí tréner akceptovat v plánovaní tréningového zat̉aženia a rozvoju tejto schopnosti venovat osobitnú pozornost'. Podl'a výsledkov iných autorov (Mačura, 2006) je vhodné tento test realizovat aj na dlhšie vzdialenosti (3,5, resp. $8 \mathrm{~m})$. Takýto spôsob realizácie testu má vyššiu afinitu k podmienkam herných situácií v basketbale.

\section{Vytrvalostné schopnosti}

Úroveň vytrvalostných schopností patrí k dôležitým predpokladov úspešnosti hráča, ktorý kombinuje rôzne zmeny smerov behu, zrýchlenie, zmenu rytmu, výskoky a osobné súboje, chôdza alebo poklus na jednotlivých úsekoch hry. Rozvoj špeciálnej vytrvalosti dáva možnost hráčovi opakovane zvládnut uvedené činností v zápase s čo najnižším poklesom intenzity, prípade znížit čas potrebný na znovuobnovenie energetických zdrojov (Laczo, 2004). Vzhl’adom na charakter tejto športovej hry, sme realizovali vytrvalostný člnkový beh na $20 \mathrm{~m}$. Test potvrdil výkonnostný rozdiel medzi hráčkami (variačné rozpätie bolo 56 úsekov). Najlepší výkon bol 103 úsekov, ktorý dosiahla najnižšia hráčka vysoká $159 \mathrm{~cm}$ a najhorší 47 úsekov hráčka s výškou $182,2 \mathrm{~cm}$. V najhoršej skupine (Q1 = 56 úsekov) bolo 9 hráčok a v najlepšej (Q3 - 70,5 úsekov) sme zaregistrovali 12 hráčok. Porovnanie s populáciou Slovenska (Sedláček \& Cihová, 2009) tejto vekovej skupiny ukázalo zaradenie hráčok do najvyšších výkonnostných skupín - nadpriemernú výkonnost̉ dosiahlo 15 hráčok a výrazne nadpriemernú až 29 dievčat. Sme si vedomí, že výsledky testu mohli byt ovplyvnené aj inými faktormi (napr. únava, vôlové vlastnosti).

\section{Výbušná sila dolných končatín}

Táto pohybová kvalita patrí v basketbale medzi rozhodujúce pohybové schopnosti na každom hernom poste. Bolo zistené, že 52-73\% bodov v zápase hráči dosiahli z výskoku (Šimonek, Doležajová \& Lednický, 2007). O význame výbušnej sily dolných končatín pre basketbalistky svedčí aj jej korelácia takmer so všetkými výsledkami sledovaných pohybových schopností (tab. 4). Na zistenie jej úrovne sme použili testy na výskokovom ergometri: výskok s protipohybom a výskok bez protipohybu. Priemerný výkon v prvom teste bol 25,47 cm. Najlepší výkon $(32,3 \mathrm{~cm})$ zaznamenala hráčka s telesnou výškou $165,5 \mathrm{~cm}$, ktorý patrila medzi najlepšie aj v rýchlostných testoch ( $20 \mathrm{~m}$ akceleračne $3,26 \mathrm{~s} ; 20 \mathrm{~m}$ s driblingom 3,39 s). Najhorší výkon bol len $17,9 \mathrm{~cm}$, ktorý dosiahla hráčka s telesnou výškou $179 \mathrm{~cm}$ a patrila aj medzi slabšie aj v rýchlostných testoch (3,73, resp. 3,89 s). Priemerný výkon vo výskoku bez protipohybu bol 23,51 cm. Najlepší výkon $(29,4 \mathrm{~cm})$ zaznamenala tá istá hráčka ako v prvom teste. Minimálny výkon v tomto teste $17,4 \mathrm{~cm}$ sme dosiahla tá istá hráčka, ako aj v prvom teste. Táto hráčka sa pohybovala na hranici najslabšej skupiny (Q1) aj v rýchlostných testoch. 
Tab. 4: Korelačná matica vybraných somatických ukazovatel'ov a pohybových schopností 14-ročných basketbalistiek $(n=44)$

\begin{tabular}{|c|c|c|c|c|c|c|c|c|c|c|c|}
\hline & Vek & TH & TV & VSHK $_{1}$ & VSHK $_{2}$ & $20 \mathrm{~m}$ & $\begin{array}{l}20 \mathrm{~m} \\
\text { dribl. }\end{array}$ & VČB & $\begin{array}{c}\text { Výskok } \\
\text { s PP } \\
\end{array}$ & $\begin{array}{l}\text { Výskok } \\
\text { bez PP } \\
\end{array}$ & Agilita \\
\hline Vek & 1 & & & & & & & & & & \\
\hline TH & 066 & 1 & & & & & & & & & \\
\hline TV & 070 & 456 & 1 & & & & & & & & \\
\hline VSHK $_{1}$ & 198 & 304 & -141 & 1 & & & & & & & \\
\hline $\mathrm{VSHK}_{2}$ & -021 & 499 & 084 & 651 & 1 & & & & & & \\
\hline $20 \mathrm{~m}$ & 048 & 375 & 412 & -146 & 040 & 1 & & & & & \\
\hline $\begin{array}{l}20 \mathrm{~m} \\
\text { dribl. }\end{array}$ & 011 & 247 & 306 & -166 & -085 & 895 & 1 & & & & \\
\hline VČB & -245 & -362 & -315 & 269 & 128 & -325 & -319 & 1 & & & \\
\hline $\begin{array}{l}\text { Výskok } \\
\text { s PP }\end{array}$ & 109 & -215 & -499 & 324 & 318 & -575 & -662 & 423 & 1 & & \\
\hline $\begin{array}{l}\text { Výskok } \\
\text { bez PP }\end{array}$ & 138 & -366 & -537 & 298 & 180 & -627 & -633 & 501 & 892 & 1 & \\
\hline Agilita & -121 & -161 & 104 & -146 & -161 & -157 & -041 & 048 & -148 & -021 & 1 \\
\hline
\end{tabular}

Legenda: Vek - decimálny vek, TH - telesná hmotnost', TV - telesná výška,VSHK - hod plnou loptou zo stoja, VSHK, hod plnou loptou zo sedu, $20 \mathrm{~m}$ - beh na $20 \mathrm{~m}$ akceleračne, $20 \mathrm{~m}$ dribl. - beh na $20 \mathrm{~m}$ akceleračne s driblingom, VČB - vytrvalostný člnkový beh na úseku $20 \mathrm{~m}$, Výskok s PP - výška výskoku s protipohybom, Výskok bez PP - výška výskoku bez protipohybu, Agilita - reakčný čas dolnou končatinou na zrakový podnet.

\section{DISKUSIA}

Väčšina trénerov sa pri výbere hráčok orientuje na dôležitý ukazovatel’ a predikciu telesnej výšky v kombinácii s výsledkami testovania pohybových schopností. Nie vždy sú však na požadovanej úrovni a tréner musí pracovat s takou skupinou, ktorú má $\mathrm{k}$ dispozícii. Zistili sme, že v tejto vekovej kategórii nemusí byt telesná výška hlavným orientačným ukazovatel’om. Relatívne nižšie hráčky s vysokou úrovňou rozvoja pohybových schopností môžu byt biologicky mladšie s perspektívou neskoršieho telesného rastu. Tento fakt potvrdila aj nehomogénnosṫ sledovanej skupiny (variačné rozpätie telesnej výšky bolo $25,9 \mathrm{~cm}$, čo zodpovedá požiadavkám na jednotlivé herné posty (rozohrávač, resp. podkošový hráč).

Je zaujímavé, že nízke rozdiely vo výsledkoch behu na $20 \mathrm{~m}$ a $20 \mathrm{~m}$ dribling $(0,03 \mathrm{~s} ; 0,06 \mathrm{~s}$; 0,07, 0,09 s) dosiahli predovšetkým hráčky, ktoré v skupine patrili medzi vyššie $(173-180,4 \mathrm{~cm})$ Najvyššia hráčka z celého súboru $(184,8 \mathrm{~cm})$ mala rozdiel časov $0,12 \mathrm{~s}$. Najväčší rozdiel medzi výsledkami obidvoch testov bol 0,40 u hráčky s výškou $171,3 \mathrm{~cm}$. Aj v teste reakčnej rýchlosti sme potvrdili nezávislost rýchlostných prejavov od telesných ukazovatel'ov. Približne rovnako vysoké hráčky $(165,5$, resp. 163,7 cm) sa ocitli na krajných hodnotách variačného rozpätia $(316,80 \mathrm{~ms})$.

V testoch zameraných na výbušnú silu horných končatín sa potvrdila závislosṫ výkonnosti od telesných ukazovatel'ov. Rezervy vidíme v technike realizácie testu hod plnou loptou zo stoja 
(autové vhadzovanie), pretože výkonnost̉ sa pohybovala aj na úrovni populácie. Pre túto špecializáciu sa vhodným testom ukázal hod plnou loptou trčaním od pŕs.

Výbušná sila dolných končatín zohráva dôležitú úlohu pri realizácii rôznych herných činností. Výsledky testovania naznačili, že v tejto schopnosti majú hráčky rezervy a tréneri by sa jej v tréningovom procese mali viac venovat. Najlepší výkon $(32,2$, resp. 29,4) cm z pohladu tejto špecializácie nie je dostatočný. Okrem jednorazového maximálneho prejavu výbušnej sily dolných končatín sa od hráča vyžaduje aj vysoký stupeň rozvoja vytrvalosti vo výbušnej sile dolných končatín, pretože potrebuje nielen jednorazový výkon, ale musí byt schopný vykonávat opakované výskoky na mieste, resp. na malom priestore.

Vytrvalostný člnkový beh je pre túto špecializáciu vhodným vzhl’adom na charakter pohybovej činnosti v zápase. Hráčky, v porovnaní s populáciu, preukázali pomerne vysokú úroveň výkonnosti. Predpokladáme, že to malo pozitívny vplyv na výsledky v teste. Napriek tomu si uvedomujeme, že významnou súčastou testu je aj motivácia a schopnost’ prekonat nepríjemné pocity zataženia.

\section{ZÁVERY}

Na základe našich poznatkov konštatujeme nasledujúce závery:

a) beh na $20 \mathrm{~m}$ s driblingom považujeme za vhodný pre sledovanú vekovú kategóriu. Na tejto vzdialenosti sa výraznejšie prejavia rýchlostné schopnosti ako aj zručnosṫ v behu s loptou v priamočiarom pohybe (šprint). Vo vyšších vekových kategóriách, po ukončení biologického vývinu odporúčame doplnit uvedený test aj behom na vzdialenost' 5 a $10 \mathrm{~m}$ hladkých aj s driblingom, ktoré majú vyššiu afinitu k špeciálnej pohybovej činnosti hráčok. Ďalšou možnostou je určit špeciálne testy podl’a hráčskych funkcií.

b) hráčky sa nemôžu spoliehat na vysokú úroveň jedného ukazovatela (napr. telesná výška, resp. rýchlostné schopnosti). To nie je zárukou vysokej výkonnosti v samotnej hre. Je len jedným z predpokladov, ktorý musí byt v súlade s d’alšími pohybovými schopnostaami a špecifickými basketbalovými zručnostami.

c) venovat zvýšenú pozornost̉ rozvoju výbušnej sily dolných a horných končatín, pretože sa potvrdila vysoká korelácia so všetkými sledovanými pohybovými schopnostami.

d) realizovat test agility nielen na vzdialenost $0,5 \mathrm{~m}$ od štartovacieho miesta, ale aj na väčšiu vzdialenost' (3-8 m).

f) pri nominácii hráčov do reprezentačných výberov je nevyhnutný komplexný prehl’ad - nielen o úrovni rozvoja pohybových schopností, ale aj o schopnostiach hráča realizovat individuálne herné činnosti, plnit taktické pokyny a jeho reakciách v nových, neočakávaných situáciách.

g) odporúčame optimalizovat skupinu testov pre uvedenú športovú špecializáciu a dlhodobo ju realizovat vo všetkých vekových kategóriách. Tak sa zabezpečí kontinuálne sledovanie každého hráča ako aj možnost’ porovnania rôznych hráčov v rovnakých vekových kategóriách.

\section{Literatúra}

Buková, A. \& Feč, R. (2014). Vplyv silového a aeróbneho tréningu na redukciu podkožného tuku, množstvo svalovej hmoty a úroveň silových schopností. Vedecká monografia. Univerzita Pavla Jozefa Šafárika v Košiciach.

Čierna, D. (2013). Koincidenčné reakčnéschopnosti vo funkčnej diagnostike športovcov. Dizertačná práca. Bratislava. Univerzita Komenského v Bratislave.

Delextrat, A. \& Cohen, D., (2008). Physiological testing of basketball players: toward a strandard evaluation of anaerobic fitness. Journal of Strength and Conditioning Research, 22(4), 1066-1072.

Erčulj, F. (2008). Testing and Evaluating the Motor Potential of Young Basketball Players. FIBA Assist Magazine, 33, $10-11$.

Erčulj, F. \& Bračič, M. (2008). Raven razvitosti nekaterih motoričnih sposobnosti mladih košarkaric iz devetnajstih evropskih držav in Slovenije. Trener košarke. 7(1), 78-84. 
Erčulj, F., Dežman, B., Vučković, G. \& Bračič, M. (2007). Testing and evaluating the motor potential of young basketball players during the 2007. FIBA international basketball camp in Postojna. Ljubljana: University of Ljubljana, Faculty of Sport.

Gallová, T., Doležajová, L., Lednický, A. \& Erčulj, B. (2010). Úroveň pohybovej výkonnosti mladých basketbalistiek. Optimální působeni tělesné zátěže 2010. Hradec Králové: Univerzita Hradec Králové, Pedagogická fakulta.

Holmberg, P. (2015). Trening agilnosti za iskusne sportaše: dinamički pristup. Kondicijski trening: stručni časopis za teoriju i metodiku kondicijske pripreme. 13(1), 4-9.

Jeffreys, I. (2006). Motor Learning - Applications for Agility, Part 1. Strength and conditioning journal [online]. 28(5) [cit. 2016-12-20]. Dostupné z: https//:www.researchgate.net/publication/232117496_Motor_LearningApplications_for_ Agility_Part_1

Kampmiller, T. (1996). Závislost’ pohybovej výkonnosti od telesného rozvoja. In R. Moravec et al. Eurofit. Telesný rozvoj a pohybová výkonnost školskej populácie na Slovensku (pp. 112-120). Bratislava: Slovenská vedecká spoločnost' pre telesnú výchovu a šport.

Kaplan, A. (2014) Připravenost reprezentačníhom,tímu basketbalistek ČR z hlediska rychlosti (nástin problému). Kondičný tréning v roku 2014. In Univerzita Mateja Bela, Filozofická fakulta Katedra telesnej výchovy a športu, Slovenská asociácia kondičných trénerov, Banská Bystrica: Zborník z medzinárodnej vedeckej konferencie: (pp. 17-29).

Labudová, J. \& Peráček, P. (2013). Agilita - pohybová schopnost' alebo pohybová zručnost'? Telesná výchova \& šport. 23(1), $12-17$.

Laczo, E. (2004). Vytrvalostné schopnosti a ich rozvoj. In R. Moravec et al. Teória a didaktika športu (pp. 117-118). Bratislava: Fakulta telesnej výchovy a športu UK.

Mačura, P. (2006). Diagnostika rýchlostných schopností basketbalistu podla smeru pohybu. In Zborník vedeckých prác Katedry hier FTVŠ UK č. 6. (pp. 36-43). Bratislava: Peter Mačura - PEEM.

Paulauskas, R. (2003). Altitude training for basketball. In FIBA ASSIST MAGAZINE 2, 59-60.

Perič, T. (2006). Výběr sportovních talentů. Praha: Grada.

Sedláček, J. \& Antala, B. (2008). Hodnotenie telesného rozvoja a motorickej výkonnosti žiakov v procese kurikulárnej transformácie výchovy a vzdelávania. Bratislava: ICM Agency.

Sedláček, J. \& Cihová, I. (2009). Športová metrológia. Bratislava: ICM Agency.

Simović, S. \& Mijanović, M. (2007). Diskriminativna analiza parametra izabranih i odbačenih kadetkinja za sudjelovanje u ljetnjoj školi sporta „Trebinje 2007“. In Ž. Bilić, Acta Kinesiologica. International Scientific Journal on Kinesiology: Vol. 1, Issue 2, December 2007, pp. 23-28.

Šimonek, J. (1987). Charakteristika kolektívnych športových hier a ich špecifické požiadavky na kondičnú prípravu. In J. Šimonek et al. Kondičná príprava v kolektívnych športových hrách (pp. 10-20). Bratislava: Šport.

Šimonek, J., Doležajová, L. \& Lednický, A. (2007). Rozvoj výbušnej sily dolných končatín v športe. Bratislava: ICM Agency.

Zemková, E. \& Hamar, D. (2014). Agility performance in athletes of different sport specializations. Acta Gymnica. [online]. 44(3), 133-140 [cit. 2017- 01-22]. Dostupné z: https://www.researchgate.net/publication/277650669_Agility_performance_in_athlet es_of_different_sport_specializations

Zemková, E. \& Hamar, D. (2001). Posudzovanie disjunktívnych reakčno-rýchlostných schopností. Bratislava: Fakulta telesnej výchovy a športu UK.

\section{Kontaktné údaje:}

PaedDr. Ladislava Doležajová, PhD.

Katedra atletiky FTVŠ UK

Nábr. arm. gen. L. Svobodu 9

81469 Bratislava

mail: ladislava.dolezajova@uniba.sk

tel.: 00421904323528 